\title{
Platelet Physiology
}

\author{
Thomas Gremmel, MD ${ }^{1,2}$ Andrew L. Frelinger III, $\mathrm{PhD}^{1} \quad$ Alan D. Michelson, MD ${ }^{1}$ \\ ${ }^{1}$ Division of Hematology/Oncology, Boston Children's Hospital, Dana- \\ Farber Cancer Institute, Boston, Massachusetts \\ 2 Department of Internal Medicine II, Medical University of Vienna, \\ Vienna, Austria \\ Address for correspondence Thomas Gremmel, MD, Center for \\ Platelet Research Studies, Division of Hematology/Oncology, Boston \\ Children's Hospital, 300 Longwood Avenue, Boston, MA \\ (e-mail: thomas.gremmel@childrens.harvard.edu; or \\ thomas.gremmel@meduniwien.ac.at).
}

Semin Thromb Hemost 2016;42:191-204.
Abstract
Keywords
- platelet function
- platelet structure
- platelet granules
- platelet surface glycoproteins
- platelet activation pathways
- platelet physiology
- review

Platelets are the smallest blood cells, numbering 150 to $350 \times 10^{9} / \mathrm{L}$ in healthy individuals. The ability of activated platelets to adhere to an injured vessel wall and form aggregates was first described in the 19th century. Besides their long-established roles in thrombosis and hemostasis, platelets are increasingly recognized as pivotal players in numerous other pathophysiological processes including inflammation and atherogenesis, antimicrobial host defense, and tumor growth and metastasis. Consequently, profound knowledge of platelet structure and function is becoming more important in research and in many fields of modern medicine. This review provides an overview of platelet physiology focusing particularly on the structure, granules, surface glycoproteins, and activation pathways of platelets.

Platelets are the smallest blood cells, numbering 150 to $350 \times 10^{9} / \mathrm{L}$ in healthy individuals. ${ }^{1}$ The ability of platelets to adhere to an injured vessel wall and form aggregates was first described in the 19th century by Bizzozero. ${ }^{2,3}$ Besides their long-established roles in thrombosis ( $\mathbf{- F i g . ~ 1 )}$ ) and hemostasis, ${ }^{4,5}$ platelets are increasingly recognized as pivotal players in numerous other pathophysiological processes including inflammation and atherogenesis, ${ }^{6}$ antimicrobial host defense, ${ }^{7}$ and tumor growth and metastasis. ${ }^{8}$ Consequently, profound knowledge of platelet structure and function is becoming more important in research and in many fields of modern medicine. This review provides an overview of platelet physiology focusing particularly on the structure, granules, surface glycoproteins (GPs), and activation pathways of platelets.

\section{Platelet Structure}

Platelets have an average diameter of 2 to $5 \mu \mathrm{m}$, a thickness of $0.5 \mu \mathrm{m}$, and a mean cell volume of 6 to $10 \mathrm{ff} .{ }^{9}$ For convenience, the structure of the platelet can be conceptually divided in a peripheral zone, a sol-gel zone, an organelle zone, and membrane systems. ${ }^{10}$

published online February 29, 2016
Issue Theme Platelet Function in Thrombosis and Hemostasis; Guest Editor: Anne-Mette Hvas, MD, PhD.

\section{Peripheral Zone}

The platelet plasma membrane is relatively smooth and has a thicker glycocalyx (GP-polysaccharide covering) than other blood cells. In high-resolution electron microscopy, it shows a wrinkled appearance with many tiny folds and the randomly distributed apertures of the open canalicular system. ${ }^{10,11}$ The glycocalyx as the platelet's exterior coat is a dynamic structure and the site of first contact with the surrounding milieu. It contains surface GPs required for the interaction of platelets with subendothelial structures of the injured vessel wall, platelet activation, platelet adhesion and aggregation, as well as clot retraction. ${ }^{12}$ In particular, the mobile receptor complexes GPIb-IX-V and integrin $\alpha \mathrm{IIb} \beta 3$ are abundantly expressed on the surface of resting platelets and are of great importance in hemostasis (see below). ${ }^{13,14}$

Below the glycocalyx is the lipid bilayer, ${ }^{15}$ which is incompressible and unstretchable. Consequently, additional membrane needed for platelet spreading must be provided by the tiny folds of the platelet surface and the internalized membrane parts of the open canalicular system. ${ }^{16}$ The lipid bilayer appears morphologically similar to the unit membranes of other cell types but plays an important role in blood coagulation. It contains tissue factor (TF), which is exposed on
Copyright $\odot 2016$ by Thieme Medical Publishers, Inc., 333 Seventh Avenue, New York, NY 10001, USA. Tel: +1(212) 584-4662.
DOI http://dx.doi.org/ 10.1055/s-0035-1564835. ISSN 0094-6176. 


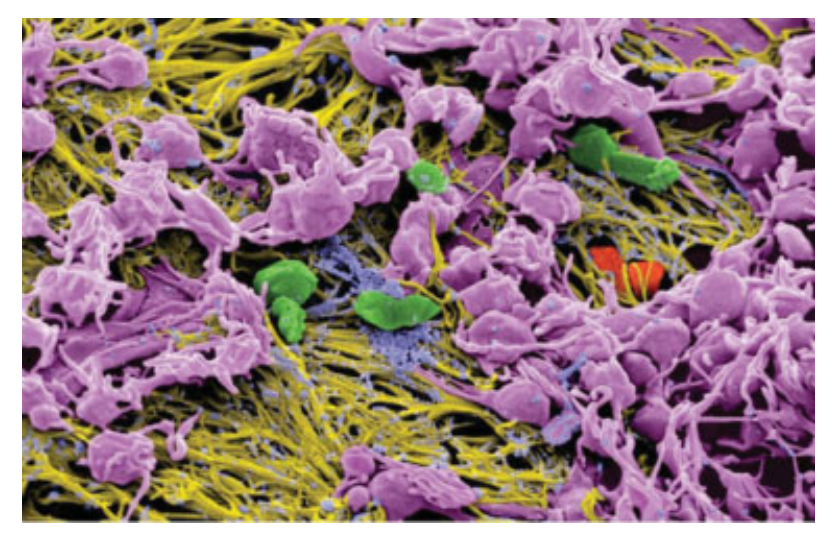

Fig. 1 Platelets in thrombosis. Scanning electron micrograph of a portion of a human coronary artery thrombus, showing many activated platelets adhering to a bed of fibrin strands. Also visible are groups of microparticles and a few cholesterol crystals and erythrocytes. (Image by John W. Weisel and Chandrasekaran Nagaswami, Department of Cell and Developmental Biology, University of Pennsylvania School of Medicine, Philadelphia, PA. Reprinted with permission from Michelson. ${ }^{1}$ )

the platelet surface in its inactive form along with negatively charged phosphatidylserine following platelet activation. ${ }^{17}$ Subsequently, activated platelets release TF-bearing microparticles (MP) capable of binding coagulation factors Va, VIIa, and $\mathrm{Xa}$ to their surface phosphatidylserine. Through the interaction of these coagulation factors with the meanwhile decrypted TF, thrombin generation is enhanced on the surface of activated platelets as well as on platelet-derived MP. ${ }^{10}$

The platelet's submembrane area lies directly under the lipid bilayer and is of great importance for platelet function. It contains a system of thin actin filaments-the membrane contractile cytoskeleton-which is required for platelet shape change and the translocation of receptors and particles over the platelet's surface. ${ }^{18}$ In the submembrane compartment, the cytoplasmic domains of all transmembrane receptors interact with proteins, many of which are associated with calmodulin, myosin, and actin filaments that constitute the above-mentioned cytoskeleton. ${ }^{19}$ Thereby, they regulate the signaling processes required for platelet activation.

\section{Sol-Gel Zone}

The transparent yet viscous matrix inside platelets is labeled the sol-gel zone. It resembles liquid gel and contains organized microtubules and microfilaments, randomly distributed glycogen, a few smooth and clathrin-coated vesicles, as well as secretory organelles. Microtubules are arranged in circumferential coils close to the cell wall, thereby forming a system that supports the membrane contractile cytoskeleton. ${ }^{20-22}$ Various experimental approaches strongly suggest that microtubules are needed for maintaining the discoid shape of human platelets. ${ }^{23,24}$ Actin microfilaments in the sol-gel zone form the cytoplasmic actin filament cytoskeleton, the matrix in which all organelles are suspended and which keeps organelles apart from each other and from the cell wall in the resting platelet. ${ }^{10,25}$ Following platelet activation, the cytoplasmic actin system constricts the microtubule coils moving $\alpha$-granules and dense bodies to the platelet center, ${ }^{26}$ which may ultimately result in the secretion of their contents through the open canalicular system. $^{25,27}$

\section{Organelle Zone}

Three major types of secretory organelles are present in platelets: $\alpha$-granules, dense granules, and lysosomes (-Table 1). In addition, platelets contain simple mitochondria, which are important for their energy metabolism, glycosomes, ${ }^{28}$ electron dense chains and clusters, ${ }^{29}$ and tubular inclusions. ${ }^{30}$

$\alpha$-granules have a round to oval shape with a diameter of 200 to $500 \mathrm{~nm}$. An average human platelet contains 50 to $80 \alpha$ granules, which makes them the most frequent organelles. ${ }^{31,32}$ In resting platelets, $\alpha$-granules are separated from each other by the cytoplasmic actin filament cytoskeleton. The fusion of $\alpha$-granules during long-term platelet storage is a first sign of cell damage. $^{33}$ In vivo, fusion of $\alpha$-granules resulting in giant $\alpha$-granules is seen in patients with Paris-Trousseau-Jacobsen syndrome, ${ }^{34}$ White platelet syndrome, ${ }^{35}$ and Medich giant platelet disorder. ${ }^{30}$ While the submembrane zone of $\alpha$-granules contains von Willebrand factor (VWF) in tube-like structures, ${ }^{36}$ various proteins are found in their peripheral zone including megakaryocyte-synthesized proteins such as coagulation factor V, thrombospondin, P-selectin, and VWF, as well as externally synthesized proteins taken up by platelets (e.g. fibrinogen). The $\alpha$-granule's central zone appears denser than its peripheral zone potentially indicating the presence of proteins with binding sites for heavy metals. ${ }^{10}$

The three to eight dense granules per normal human platelet are smaller than $\alpha$-granules and display great morphological variability. ${ }^{37}$ Their most prominent feature is an electron-opaque spherical structure, which is usually surrounded by an empty space. However, in some dense granules, this space is traversed by filaments or filled with a granule-like substance. ${ }^{10}$ Besides adenine nucleotides such as adenosine triphosphate (ATP) and adenosine diphosphate (ADP), dense granules contain serotonin, pyrophosphate, calcium, and magnesium (see below).

Other electron-opaque structures in the cytoplasm are chains and clusters of hexagonal beads which are present in 2 to $22 \%$ of human platelets and seem to increase with age. ${ }^{29}$ The origin and function of these electron-dense formations remains unknown. It was previously speculated that electron-dense chains and clusters represent precursors of dense granules, but this hypothesis was abandoned after studying patients with storage pool diseases, whose platelets lacked dense granules while containing the usual amount of chains and clusters. $^{38}$

Human platelets also contain 0 to 2 spherical lysosomes, which are slightly smaller than $\alpha$-granules. Their content comprises at least 13 acid hydrolases, cathepsin D and E, lysosomal-associated membrane protein (LAMP)-2, and $\mathrm{CD63}$, and can be released in response to strong platelet stimulation in vitro. However, the role of lysosomes in platelet function and hemostasis remains largely unknown. ${ }^{10}$ 
Table 1 General features of platelet granule types

\begin{tabular}{|l|l|l|l|l|l|}
\hline & Number/platelet & Diameter $(\mathrm{nm})$ & $\begin{array}{l}\text { Surface area } \\
\left(\mu \mathrm{m}^{2}\right) / \text { platelet }\end{array}$ & Common markers & General function \\
\hline$\alpha$-granules & $50-80$ & $200-500$ & 14 & $\begin{array}{l}\text { VWF } \\
\text { CXCL4 (PF4) } \\
\text { P-selectin }\end{array}$ & $\begin{array}{l}\text { Hemostasis/thrombosis } \\
\text { Inflammation } \\
\text { Angiogenesis } \\
\text { Host defense } \\
\text { Mitogenesis }\end{array}$ \\
\hline Dense granules & $3-8$ & 150 & $<1$ & $\begin{array}{l}\text { CD63 } \\
\text { Serotonin }\end{array}$ & $\begin{array}{l}\text { Hemostasis/thrombosis } \\
\text { Inflammation }\end{array}$ \\
\hline Lysosomes & $<3$ & $200-250$ & $<1$ & Acid phosphatase & Endosomal digestion \\
\hline
\end{tabular}

Abbreviations: CXCL4, chemokine (C-X-C motif) ligand 4; PF4, platelet factor 4; VWF, von Willebrand factor. Source: Reprinted with permission from Flaumenhaft. ${ }^{51}$

The glycogen-containing platelet glycosome is another component of the platelet's organelle zone. ${ }^{28}$ Glycosomes have a round or oval shape, and a similar size to $\alpha$-granules so that they can easily be confused with glycogen-bearing $\alpha$ granules. Tubular inclusions, which often contain glycogen as well, can be discriminated from glycosomes by their multilamellar membrane.

Finally, mitochondria are seen in the organelle zone. Despite their low number and simple structure, they provide the platelet's energy requirements, and make sure that a blockade of anaerobic glycolysis does not impair platelet function. Although mitochondria are also seen as important providers of calcium by some authors, other investigations favor the dense tubular system and extracellular calcium as the major calcium sources in platelet activation. ${ }^{39}$

\section{Membrane Systems}

Besides the outer plasma membrane, the membrane systems in human platelets comprise Golgi complexes, the surfaceconnected open canalicular system, the dense tubular system, and the rough endoplasmic reticulum.

Residues of megakaryocytic Golgi complexes are observed in less than $1 \%$ of normal human platelets but can be found more frequently in patients with certain hypogranular platelet disorders. ${ }^{35,40}$ The presence of Golgi complexes in platelets from patients with hypogranular syndromes such as White platelet syndrome may indicate ongoing granulopoiesis. ${ }^{35}$

The open canalicular system is a part of the platelet's surface membrane, which extends toward the interior of the platelet and in doing so forms a tubular structure, ${ }^{41-43}$ which exerts three major functions. Its channels can be used for the transport of plasma components such as fibrinogen to $\alpha$-granules ${ }^{44-46}$ and can also serve as route for the release of granular contents during platelet activation. ${ }^{27}$ Moreover, the channels of the open canalicular system can be evaginated and thereby provide membrane parts needed for platelet spreading following platelet adhesion to an injured vessel wall. ${ }^{47}$ Through this mechanism, activated platelets are able to increase their surface area more than fourfold compared with resting discoid platelets. ${ }^{48}$

The dense tubular system is a residuum of the parent megakaryocyte's smooth endoplasmic reticulum and consists of channels randomly dispersed in the platelet cytoplasm. The channels are separated from the canaliculi of the open canalicular system which appear empty by electron microscopy and-in contrast to them-contain an amorphous substance resembling the surrounding cytoplasm in opacity. ${ }^{41}$

Channels of rough endoplasmic reticulum are only seen in patients with fast platelet turnover due to immune thrombocytopenia and are then usually studded with ribosomes. ${ }^{10}$

\section{Platelet Granules}

Platelet granules were first described in the late 19th century, but it took until 1966 to differentiate dense granules from $\alpha$ granules, ${ }^{49}$ and another year to distinguish the latter from lysosomes by the then newly developed method of electron microscopy (-Table 1). ${ }^{50}$

\section{Formation of Platelet Granules}

The formation of platelet granules is initiated in the megakaryocyte, but their maturation continues in the circulating platelet. $^{51}$

\section{$\alpha$-Granules}

The proteins stored in $\alpha$-granules are provided by synthesis and endocytosis. While synthesized proteins are transported from the endoplasmic reticulum to the trans-Golgi network, where they are packaged in immature granules, ${ }^{52,53}$ plasma proteins are taken up by megakaryocytes via the endocytotic pathway and uptake of plasma proteins via this pathway continues in the mature platelet. ${ }^{51}$ Membrane trafficking required for both pathways is mediated by coat proteins such as clathrin, adaptor proteins (AP)-1, AP-2, AP-3, and other vesicle trafficking proteins, for example, soluble $\mathrm{N}$-ethylmaleimide sensitive fusion protein (NSF) attachment protein receptors (SNAREs) and monomeric GTPases such as Rabs. Thus, for both pathways, clathrin-coated vesicles are formed through membrane invagination under the influence of $\mathrm{AP}^{51}$ However, differences exist: AP-1 appears to play a pivotal role in the synthetic pathway, ${ }^{31}$ whereas AP-2 mediates endocytosis. ${ }^{54}$ The resulting vesicles from the trans-Golgi network or the plasma membrane are then moved to multivesicular bodies, which represent transient structures at an intermediate stage of 
granule production in megakaryocytes. ${ }^{55}$ Multivesicular bodies are involved in $\alpha$-granule and dense granule sorting, ${ }^{55,56}$ and kinetic studies have shown that endocytosed proteins are transported from endosomes to immature multivesicular bodies to mature multivesicular bodies to $\alpha$-granules. ${ }^{51}$ The latter contain small vesicles called exosomes, ${ }^{55}$ which in part persist in mature $\alpha$-granules and can be released following platelet activation. ${ }^{57}$ Megakaryocyte-derived granules are transferred to the nascent platelets on microtubule tracks during proplatelet formation. ${ }^{51}$

\section{Dense Granules}

Dense granules are lysosome-related organelles, which means that they originate from the endosomal system rather than from the trans-Golgi network. ${ }^{58}$ In the endosomal compartment, biogenesis of lysosome-related organelle complexes (BLOCs) are involved in vesicle trafficking required for dense granule formation. ${ }^{51}$ Besides BLOCs-1, -2 , and $-3,{ }^{59-62}$ AP-3 plays an important role in dense granule formation, and like defects in BLOC- 2 or $-3,{ }^{63}$ certain mutations in the AP- 3 gene are associated with dense granule deficiency in HermanskyPudlak syndrome. During megakaryopoiesis, dense granules appear concomitantly with $\alpha$-granules, and like $\alpha$-granules, early dense granules are also sorted in multivesicular bodies. ${ }^{56}$ Their content becomes denser as they mature, most likely due to increased membrane pump activity. ${ }^{51}$

\section{Granule Content}

\section{$\alpha$-Granules}

$\alpha$-granules contain membrane-associated and soluble proteins, which are involved in various processes including cell adhesion, coagulation, inflammation, cell growth, and host defense ( - Table 2). Following platelet activation, membranebound granule proteins are expressed on the platelet surface, whereas soluble granule proteins are released into the extracellular compartment. Most of the membrane-bound proteins are already present on the surface of resting platelets, ${ }^{37}$ for example, integrins such as $\alpha \mathrm{IIb} \beta 3$, immunoglobulin family receptors such as GPVI, Fc receptors $(\mathrm{FcR})$, platelet endothelial cell adhesion molecule, the GPIb-IX-V complex, tetraspanins, CD36, and Glut- $3 .{ }^{64,65}$ However, some membrane-associated proteins including fibrocystin L, CD109, and P-selectin are exclusively expressed on the surface of activated, rather than resting, platelets. ${ }^{64}$ In particular, platelet surface P-selectin expression is therefore widely used as a sensitive flow cytometric marker of platelet activation (- Fig. 2) ${ }^{66-68}$

Proteins in platelet releasate can derive from different platelet granules, exosomes, and from cleavage of initially surface-bound proteins. However, proteomic analyses have identified more than 300 soluble proteins released by $\alpha$ granules. ${ }^{64,69}$ Many of the released proteins are also found in human plasma, prompting questions as to how the $\alpha$-granule constituents differ from their plasma counterparts in structure or function.

\section{Dense Granules}

Platelet dense granules contain high concentrations of adenine nucleotides, namely, ADP and ATP, ${ }^{70}$ uracil and guanine nucleotides, calcium, and potassium (-Table 3 ). Moreover, polyphosphates and bioactive amines such as serotonin and histamine are present in platelet dense granules. ${ }^{71,72}$ The milieu within platelet dense granules is kept at a $\mathrm{pH}$ of approximately 5.4 by a $\mathrm{H}^{+}$-ATPase

Table 2 a-granule contents

\begin{tabular}{|c|c|}
\hline Type & Examples \\
\hline Integral membrane proteins & allb $\beta 3$, GPIb-IX-V, GPVI, P-selectin \\
\hline Coagulants, anticoagulants, and fibrinolytic proteins & $\begin{array}{l}\text { Factors } \mathrm{V}, \mathrm{IX}, \mathrm{XIII} \text {, antithrombin, protein } \mathrm{S} \text {, tissue } \\
\text { factor pathway inhibitor, plasminogen, } \\
\alpha_{2} \text {-macroglobulin }\end{array}$ \\
\hline Adhesion proteins & Fibrinogen, von Willebrand factor, thrombospondin \\
\hline Chemokines & $\begin{array}{l}\text { CXCL1 (GRO- } \alpha \text { ), CXCL4 (PF4), CXCL5 (ENA-78), } \\
\text { CXCL8 (IL8), CCL2 (MCP-1), CCL3 (MIP-1 } \alpha) \text {, CCL5 } \\
\text { (RANTES) }\end{array}$ \\
\hline Growth factors & $\begin{array}{l}\text { Epidermal growth factor, hepatocyte growth factor, } \\
\text { insulin-like growth factor, transforming growth } \\
\text { factor } \beta\end{array}$ \\
\hline Angiogenic factors and inhibitors & $\begin{array}{l}\text { Vascular endothelium growth factor, fibroblast } \\
\text { growth factor, platelet-derived growth factor, } \\
\text { angiostatin, endostatin }\end{array}$ \\
\hline Microbicidal proteins & Thymosin- $\beta 4$, thrombocidins 1 and 2 \\
\hline Immune mediators & $\begin{array}{l}\text { Complement C3 precursor, complement C4 } \\
\text { precursor, IgG }\end{array}$ \\
\hline
\end{tabular}

Abbreviations: $C C L$, chemokine (C-C motif) ligand; $C X C L$, chemokine (C-X-C motif) ligand; ENA-78, epithelial-derived neutrophil-activating peptide 78; GP, glycoprotein; GRO- $\alpha$, growth-regulated oncogene $\alpha$; IgG, immunoglobulin G; IL8, interleukin 8; MCP-1, monocyte chemotactic protein 1; MIP-1 $\alpha$, macrophage inflammatory protein $1 \alpha$; PF4, platelet factor 4; RANTES, regulated on activation normal T cell expressed and secreted. Source: Reprinted with permission from Flaumenhaft. ${ }^{51}$ 


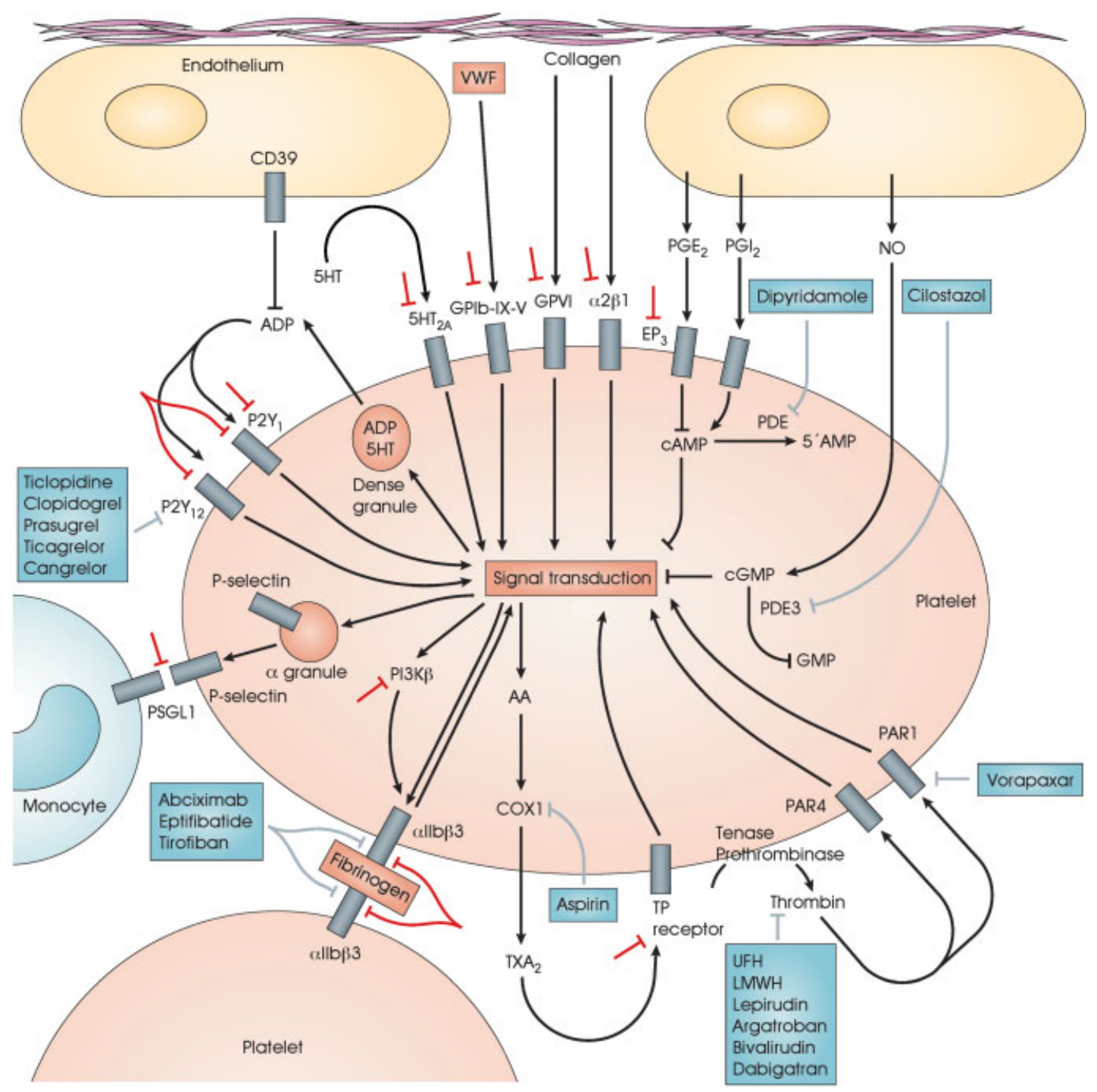

Fig. 2 Platelet function and molecular targets of antiplatelet agents. Initial platelet adhesion to damaged vessel walls is mediated by the binding of exposed collagen to platelet surface GPVI and integrin $\alpha 2 \beta 1$ and by the binding of VWF to the platelet surface GPIb-IX-V complex. This complex is also a receptor for other platelet ligands (thrombospondin, collagen, and P-selectin), leukocyte integrin $\alpha M \beta 2$, and procoagulant factors (thrombin, kininogen, factor XI, and factor XII). Thrombin, generated by the coagulation cascade, is a potent activator of human platelets through two platelet surface receptors: PAR-1 and PAR-4. Three groups of platelet surface receptors provide important positive feedback loops for platelet activation: $\mathrm{P} 2 \mathrm{Y}_{1}$ and $\mathrm{P} 2 \mathrm{Y}_{12}$ are stimulated by $\mathrm{ADP}$ released from platelet dense granules; $5 \mathrm{HT} 2 \mathrm{~A}$ receptors ( $5 \mathrm{HT}_{2 \mathrm{~A}}$ ) are stimulated by $5 \mathrm{HT}$ (also known as serotonin) released from platelet dense granules; and the thromboxane prostanoid (TP) receptor is stimulated by $T X A_{2}$ generated by the platelet COX1-dependent signaling pathway. Platelet-to-platelet aggregation is mediated by fibrinogen and, at high shear flow, by VWF binding to activated integrin $\alpha \mathrm{llb} \beta 3$. Perpetuation of platelet-to-platelet aggregation is augmented by other receptors, including JAMA and JAMC, growtharrest specific gene 6 receptor and ephrin. Platelet-monocyte adhesion is initially mediated by the binding of platelet surface P-selectin to its constitutively expressed cognate receptor, PSGL1, on the monocyte surface. Activated platelets, monocytes, and microparticles bind coagulation factors and provide a surface for the generation of a fibrin clot. Approved antiplatelet agents and their molecular targets are shown in boxes. Indirect inhibitors (UFH, LMWH) and direct inhibitors (lepirudin, argatroban, bivalirudin, and dabigatran) of thrombin, unlike PAR-1 antagonists, are anticoagulants rather than specific antiplatelet drugs. However, their inhibition of thrombin results in reduced platelet activation. Investigational strategies for novel antiplatelet agents are shown by the symbols adjacent to: GPIb-IX-V, GPVI, $\alpha 2 \beta 1, E P_{3}, 5 H T_{2 A}, P 2 Y_{1}, P 2 Y_{12}$,

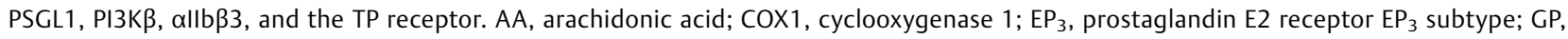
glycoprotein; JAMA, junctional adhesion molecule A; JAMC, junctional adhesion molecule C; LMWH, low-molecular-weight heparin; NO, nitric oxide; PAR, protease-activated receptor; PDE, phosphodiesterase; PG, prostaglandin; PI3K $\beta$, phosphoinositide 3-kinase $\beta$-isoform; PSGL1, P-selectin glycoprotein ligand-1; TXA 2 , thromboxane A2; UFH, unfractionated heparin; VWF, von Willebrand factor; 5HT, 5-hydroxytryptamine. (Modified with permission from Michelson. ${ }^{68}$ )

proton pump. $^{73}$ Furthermore, the multidrug resistance protein 4 has been described on platelet dense granules and is considered responsible for the uptake of adenine nucleotides, ${ }^{74}$ whereas serotonin is trafficked from platelet cytoplasm into dense granules by the vesicular monoamine transporter 2 . The latter may also concentrate histamine into platelet dense granules. ${ }^{75} \mathrm{GPIb}$, integrin $\alpha \mathrm{IIb} \beta 3$, CD63 (granulophysin), and LAMP-2 are among the 
Table 3 Dense granule contents

\begin{tabular}{|l|l|}
\hline Type & Examples \\
\hline Cations & $\mathrm{Ca}^{2+}, \mathrm{Mg}^{2+}, \mathrm{K}^{+}$ \\
\hline Phosphates & Polyphosphate, pyrophosphate \\
\hline Bioactive amines & Serotonin, histamine \\
\hline Nucleotides & ADP, ATP, UTP, GTP \\
\hline
\end{tabular}

Abbreviations: ADP, adenosine diphosphate; ATP, adenosine triphosphate; GTP, guanosine triphosphate; UTP, uridine triphosphate. Source: Reprinted with permission from Flaumenhaft. ${ }^{51}$

membrane-associated proteins found in platelet dense granules. ${ }^{76}$

\section{Lysosomes}

Platelet lysosomes bear protein degrading enzymes such as cathepsins, elastase, and collagenase; carbohydrate degrading enzymes such as glucosidase and galactosidase; and acid phosphatase as phosphate ester cleaving enzyme ( - Table 4 ). LAMP-1, LAMP-2, and CD63 are found in the lysosomal membrane in a highly glycosylated state and support its protective function. $^{51}$

\section{Granule Secretion}

Mechanisms of Platelet Granule Secretion

Membrane fusion plays a key role in platelet granule secretion. Following platelet activation, platelet granules accumulate in the cell center during platelet shape change, and may fuse with one another in homotypic fusion. ${ }^{77}$ In a further step, granules fuse with the open canalicular system releasing their contents into its channels and thereby finally to the extracellular space. ${ }^{45,78}$ Another mechanism of granule release is the direct fusion of platelet granules with the plasma membrane. ${ }^{79}$ Soluble $N$-ethylmaleimide-sensitive factor attachment protein receptors (SNAREs) on platelet granules, namely, vesicular SNAREs (vSNAREs) and so-called target SNAREs (tSNAREs), associated with the plasma membrane and the open canalicular system mediate the fusion of platelet granules with one another, the open canalicular system and the plasma membrane. ${ }^{80,81}$ Vesicleassociated membrane protein (VAMP)-8 is considered the most important vSNARE for platelet granule release, whereas VAMPs-

Table 4 Lysosomal contents

\begin{tabular}{|l|l|}
\hline Type & Examples \\
\hline Protein degrading enzymes & $\begin{array}{l}\text { Cathepsins, elastase, } \\
\text { collagenase, } \\
\text { carboxypeptidase }\end{array}$ \\
\hline Carbohydrate degrading enzymes & $\begin{array}{l}\text { Glucosidase, } \\
\text { galactosidase, } \\
\text { mannosidase }\end{array}$ \\
\hline Phosphate ester cleaving enzymes & Acid phosphatase \\
\hline
\end{tabular}

Source: Reprinted with permission from Flaumenhaft. ${ }^{51}$
2 and -3 may play minor roles. ${ }^{80,82,83}$ Syntaxins $2,4,7,11$, and 12 and SNAP-23, -25, and -29 have been described as tSNAREs. ${ }^{82,84-86}$ The function of SNAREs in platelet granule secretion is regulated by chaperone proteins such as the $\mathrm{Mg}^{2+}$-dependent ATPase NSF. ${ }^{87}$ NSF disassembles membraneassociated SNARE complexes thereby enabling their interaction with cognate SNAREs on opposing membranes. Its important role in the platelet release reaction is exemplified by studies showing that inhibitory peptides and antibodies to NSF impair platelet $\alpha$-granule release. ${ }^{87,88}$ Other important players in platelet granule release are Sec1/Munc proteins and Rab proteins, which can influence the function of SNAREs. ${ }^{89-94}$

In addition, the membrane's lipid composition affects its ability to fuse. ${ }^{95}$ The platelet cytoskeleton is also involved in granule secretion. Although actin polymerization seems to inhibit $\alpha$-granule and dense granule release in the resting platelet, ${ }^{96}$ it facilitates granule secretion during platelet activation. ${ }^{97}$

Furthermore, actomyosin contraction may foster granule secretion. ${ }^{98-100}$ Microtubules are considered a minor player in platelet granule release since mice with microtubule deficiencies exhibit only a modest impairment of granule secretion. ${ }^{101,102}$

Similar to other cells, the increase of intracellular $\mathrm{Ca}^{++}$ supports granule secretion in platelets. ${ }^{103}$ Finally, several protein $C$ kinase isoforms take part in the platelet release reaction. In particular, protein $C$ kinase isoforms $\alpha$ and $\beta$ support granule secretion, ${ }^{104}$ while others differentially affect granule release. ${ }^{104-106}$

\section{Functions of Platelet Granule Secretion}

Platelet granule secretion is involved in hemostasis and thrombosis, inflammation, atherogenesis, antimicrobial host defense, and mitogenesis. ${ }^{51}$

Upon platelet activation, $\alpha$-granules release fibrinogen and VWF, which promote platelet-platelet and plateletendothelial cell interactions. Furthermore, the fibrinogen receptor $\alpha I I b \beta 3$, the collagen receptor GPVI, and components of the VWF receptor complex GPIb-IX-V, which are found in $\alpha$-granules, are expressed on the platelet surface and subsequently support platelet adhesion. ${ }^{37,107}$ By releasing coagulation factors such as factors V and IX, ${ }^{108} \alpha$-granules also participate in secondary hemostasis. Finally, $\alpha$-granules may be involved in the maintenance of hemostatic balance by secreting proteins that limit coagulation including antithrombin, protein $\mathrm{S}$, and TF pathway inhibitor. ${ }^{109,110}$ The contribution of $\alpha$-granules to normal hemostasis is evidenced by the bleeding tendency in patients with gray platelet syndrome. ${ }^{111}$ Based on their content, an involvement of $\alpha$-granules in thrombosis is expected ${ }^{64,69}$ although their exact role remains to be determined.

Dense granules participate in hemostasis and thrombosis as the primary source of ADP, which acts as a strong platelet agonist at sites of vascular injury. Moreover, the secretion of serotonin by dense granules supports platelet aggregation and promotes vascular tone, ${ }^{112}$ while released $\mathrm{Ca}^{++}$and polyphosphates contribute to clot formation..$^{51}$ On the contrary, some of the released diadenosine polyphosphates are 
partial antagonists of the ADP receptors and may be involved in limiting platelet activation once it has begun. ${ }^{113,114}$ The importance of dense granules in normal hemostasis is exemplified by the bleeding diathesis in patients with HermanskyPudlak syndrome or Chediak-Higashi syndrome, whereas their involvement in thrombus formation has been proven by in vitro and in vivo experiments. ${ }^{115,116}$

Both $\alpha$-granules and dense granules are involved in inflammatory processes. $\alpha$-granules provide platelet surface receptors enabling the interaction with leukocytes and endothelial cells, ${ }^{117,118}$ thereby leading to mutual activation, cell recruitment, and propagation of their inflammatory phenotype. ${ }^{119}$ Furthermore, $\alpha$-granules release numerous proinflammatory and immune-modulating factors fostering recruitment and activation of inflammatory cells, chemokine secretion, as well as cell differentiation..$^{120-123}$ The role of $\alpha$-granules in atherosclerosis is mostly attributable to their proinflammatory actions. ${ }^{124}$

Dense granules can secrete polyphosphates and thus initiate the generation of bradykinin, ${ }^{112}$ which supports vascular permeability and edema in vivo. ${ }^{125}$ An involvement of dense granules in atherogenesis has been shown in mice with dense granule deficiency. ${ }^{126}$

$\alpha$-granules participate in host defense by providing various antimicrobial proteins, for example, chemokine (C-X-C motif) ligand 4 (CXCL4), derivatives of CXCL7, CCL5 (RANTES), and thymosin- $\beta 4,{ }^{127}$ as well as complement and complement-binding proteins. ${ }^{64}$

Proangiogenic proteins such as vascular endothelial growth factor, platelet-derived growth factor, fibroblast growth factor, epidermal and insulin-like growth factor, ${ }^{128}$ as well as inhibitors of angiogenesis including thrombospondin-1, CXCL4, angiostatin, and endostatin have been identified in $\alpha$-granules. ${ }^{129,130}$ Recent studies suggest that pro- and antiangiogenic factors are released agonist specifically. ${ }^{130-132}$ Besides angiogenesis, $\alpha$-granule secretion may play a role in tumor growth and stability, ${ }^{133}$ metastasis, ${ }^{134,135}$ and wound healing. ${ }^{136,137}$

\section{Platelet Surface Glycoproteins}

Although there are many types of platelet surface GPs, ${ }^{138}$ the GPIb-IX-V complex, GPVI, and integrin $\alpha$ IIb $\beta 3$ (also known as GPIIb/IIIa) are considered the most important platelet surface GPs mediating platelet adhesion, activation, and aggregation, respectively, and their structures and functions will therefore be described in more detail below.

\section{GPIb-IX-V Complex}

The GPIb-IX-V complex acts as platelet surface receptor and is heavily involved in normal hemostasis as well as in arterial thrombosis. ${ }^{139,140}$

\section{Structure}

Human GPIb $\alpha$ is a type-I, membrane-spanning GP with an $\mathrm{N}$-terminal, ligand-binding domain, a sialomucin core, a transmembrane region, and a cytoplasmic tail. ${ }^{141}$ Its major ligand-binding domain comprises seven tandem leucine-rich repeats, an $\mathrm{N}$-terminal capping sequence, a C-terminal flanking sequence, and an anionic sequence. ${ }^{139,142-144}$ GPIb $\alpha$ and GPIX are present at approximately 25,000 copies per platelet, whereas GPV is present at approximately 12,500 copies. ${ }^{145}$

\section{Function}

GPIb-IX-V propagates the adhesion of activated platelets to endothelial cells and subendothelial structures of the injured vessel wall, mainly by binding its most important ligand VWF, which is itself able to bind collagen (-Fig. 2). ${ }^{146}$ Another ligand for GPIb-IX-V is thrombospondin, which seems to mediate platelet adhesion at high shear rates in the absence of VWF. ${ }^{147}$ It has been shown that GPIb $\alpha$ can also bind P-selectin, thereby offering another mechanism of plateletendothelial cell and platelet-platelet interactions. ${ }^{148}$ Furthermore, $\alpha \mathrm{M} \beta 2$ (Mac-1) serves as a counter receptor for GPIbIX-V, enabling the attachment of platelets to leukocytes. ${ }^{149}$

Besides its role in platelet adhesion, GPIb-IX-V assembles procoagulant activity on activated platelets by providing binding sites for $\alpha$-thrombin, factor XI, and high-molecularweight kininogen. ${ }^{142,150,151}$ On the contrary, the binding of factor XII to GPIb $\alpha$ competes with kininogen binding and inhibits thrombin-dependent platelet aggregation associated with thrombin binding to GPIb $\alpha .^{152}$

Finally, complex signaling processes are initiated by crosslinking of GPIb-IX-V by VWF or other multivalent ligands, ultimately resulting in the activation of $\alpha \operatorname{Ilb} \beta 3$ and ectodomain shedding of GPIb $\alpha^{140,141,153-155}$

\section{Glycoprotein VI}

GPVI is the major signaling receptor for collagen on human platelets, and exerts functions in hemostasis and other platelet-mediated processes. ${ }^{156-159}$

\section{Structure}

GPVI belongs to the immunoglobulin superfamily of receptors. It consists of 319 amino acids and is present at approximately 3,700 copies per platelet. ${ }^{145,160}$ GPVI comprises two extracellular immunoglobulin domains, D1 and D2, which are connected by a peptide strand and linked to the transmembrane domain via a glycosylated stem. ${ }^{160}$ The cytoplasmic domain of human GPVI consists of 51 amino acids and shows an amino acid-rich area near the transmembrane region and a proline-rich area. ${ }^{160-162}$ GPVI exists as a complex with the FCR $\gamma$-chain, which is expressed on platelets in monomeric and dimeric forms. ${ }^{163,164}$ The monomeric form is particularly present on unactivated platelets and its affinity for collagen is too low to allow activation in response to physiological concentrations of collagen. ${ }^{165,166}$ In contrast, the dimeric form has an increased affinity for collagen and binding of collagen to the dimeric complex may result in intracellular signals leading to the generation of further dimers. Without the FCR $\gamma$-chain, GPVI does not reach the platelet surface and collagen-induced platelet activation is not initiated. ${ }^{167}$

\section{Function}

Platelets adhere to exposed collagen fibers by binding of immobilized VWF to GPIb-IX-V. ${ }^{160}$ This allows binding of collagen to 
low-affinity GPVI and results in intracellular signals with subsequent inside-out activation of integrins including $\alpha 2 \beta 1$ and $\alpha$ IIb $\beta 3$ as well as further clustering of GPVI (-Fig. 2). Thereby, GPVI activation is reinforced, and stable platelet adhesion and spreading are promoted through binding of $\alpha 2 \beta 1$ and $\alpha$ IIb $\beta 3$ to collagen and VWF, respectively. ${ }^{168,169}$

Following activation by collagen and other agonists, GPVI is rapidly shed from platelet surface, most likely to prevent excessive collagen-stimulated megakaryocyte and platelet activation in the bone marrow and after minor damages to the vasculature. ${ }^{160}$

Inherited defects in GPVI in two patients were only associated with a mild bleeding syndrome suggesting that hemostasis may not be the primary role of the GPVI receptor complex. ${ }^{160,170,171}$ GPVI may also be involved in processes beyond hemostasis, ${ }^{172}$ for example, in the pathogenesis of rheumatoid arthritis and the development of the cardiovascular system. ${ }^{173,174}$

\section{Integrin $\alpha$ Ilb $\beta 3$}

Platelet surface integrin $\alpha$ IIb $\beta 3$ (previously termed GPIIb/IIIa) is transformed from its resting low-affinity state to a highaffinity receptor as the final step of platelet activation and subsequently mediates platelet aggregation at a molecular level (-Fig. 2). ${ }^{175,176}$

\section{Structure}

$\alpha$ IIb $\beta 3$ belongs to the integrin family of cell adhesion molecules $^{177-179}$ and is found on platelets, megakaryocytes, mast cells, basophils, and some tumor cells. ${ }^{180-185}$ With 80,000 to 100,000 copies per platelet, ${ }^{186,187}$ it constitutes the major integral plasma membrane protein on human platelets accounting for $17 \%$ of the platelet membrane protein mass. ${ }^{188}$ Moreover, $\alpha \operatorname{Ilb} \beta 3$ is present in platelet $\alpha$-granule membranes and can become expressed following platelet activation. ${ }^{189,190}$

$\alpha \mathrm{IIb} \beta 3$ is a heterodimer consisting of an $\alpha$ IIb and $\beta 3$ subunit, both synthesized as single glycosylated polypeptide chains. ${ }^{191} \alpha$ IIb consists of 1,008 amino acids, ${ }^{192}$ whereas $\beta 3$ is composed of 762 amino acids. ${ }^{193,194}$ Both subunits comprise a large extracellular domain, a transmembrane segment, and a short cytoplasmic tail, ${ }^{193-196}$ and are arranged on the platelet surface in a type- 1 orientation with the $\mathrm{N}$-terminus residing in the extracellular region and the $\mathrm{C}$-terminus within the cytosol. ${ }^{197}$

\section{Function}

Agonist-induced platelet activation triggers intracellular signaling events that converge at the cytoplasmic tails of $\alpha I I b \beta 3$ and are then transmitted across the platelet membrane via inside-out signaling ultimately resulting in the transformation of the extracellular domain of $\alpha$ IIb $\beta 3$ into a high-affinity receptor for fibrinogen and VWF. ${ }^{176,197,198}$ By binding divalent fibrinogen or multivalent $\mathrm{VWF}^{176,198}$ activated $\alpha$ IIb $\beta 3$ enables platelet-platelet interactions and consequently the formation of platelet aggregates. Moreover, by binding vitronectin, fibronectin, or thrombospondin-1, ${ }^{199-201}$ activated $\alpha$ IIb $\beta 3$ may also mediate platelet adhesion to subendothelial structures and regulate platelet aggregation. $^{197}$

The role of activated $\alpha$ IIb $\beta 3$ in platelet aggregation makes it a prime target for antithrombotic therapy ( - Fig. 2). Indeed, antibodies, peptides, and nonpeptides binding to $\alpha$ IIb $\beta 3$ have been shown to effectively block $\alpha$ IIb $\beta 3$-mediated plateletplatelet bridging, and three GPIIb/IIIa receptor antagonists are currently approved to prevent and treat detrimental platelet aggregation in patients undergoing percutaneous coronary interventions. ${ }^{202,203}$

\section{Platelet Activation Pathways}

Human platelets can be activated by numerous agonists via different pathways. ${ }^{204}$ Besides the above-discussed processes of VWF- and collagen-induced platelet activation, in particular, thrombin and ADP play major roles in human platelet activation (-Fig. 2 ).

\section{Thrombin}

The serine protease thrombin is the most potent platelet agonist and activates platelets via protease-activated receptors (PARs) and GPIb-IX-V. ${ }^{205-209}$ The four PARs belong to the superfamily of G-protein-coupled receptors with seven transmembrane-spanning $\alpha$-helices, four extracellular loops and domains, and four intracellular loops and domains. ${ }^{210}$ PAR-1 and PAR-4 mediate most of the platelet response to thrombin on human platelets, ${ }^{205,211}$ whereas PAR-2 is not expressed on platelets and PAR-3 functions only as a cofactor for thrombin activation of PAR-4. ${ }^{212}$ While PAR- 1 is sensitive to low levels of thrombin, PAR-4 triggers platelet activation and aggregation only at high thrombin concentrations, and cleavage of PAR-4 by thrombin occurs 20- to 70-fold slower than cleavage of PAR-1. ${ }^{213}$ Moreover, anti-PAR-1 blocking antibodies and PAR-1 antagonists blocked the activation of platelets by low concentrations of thrombin, whereas antiPAR-4 blocking antibodies did not affect thrombin-inducible platelet activation. ${ }^{211}$ Therefore, PAR- 1 is the most important receptor for the activation of human platelets by thrombin. In 2014, the first PAR-1 receptor antagonist (-Fig. 2) was approved for clinical use in patients with a history of myocardial infarction or peripheral arterial disease to prevent thrombotic cardiovascular events based on the results of two large clinical trials. ${ }^{214,215}$

\section{Adenosine Diphosphate}

$\mathrm{ADP}$ is one of the major components of the releasate from activated platelets, and its critical role in the process of platelet activation and aggregation was recognized more than 50 years ago. ${ }^{216}$ It acts as an agonist at two platelet purinergic $\mathrm{G}$-protein coupled receptors-the Gq-coupled $\mathrm{P}_{2} \mathrm{Y}_{1}$ and the Gi-coupled $\mathrm{P}_{2} \mathrm{Y}_{12}$ receptor. Like other $\mathrm{P} 2 \mathrm{Y}$ receptors, $\mathrm{P}_{2} \mathrm{Y}_{1}$ and $\mathrm{P} 2 \mathrm{Y}_{12}$ are seven-membrane-spanning proteins with a carboxyl terminal domain on the cytoplasmic side and an amino terminal domain being exposed to the extracellular environment. ${ }^{217}$ $\mathrm{P}_{2} \mathrm{Y}_{1}$ activation initiates ADP-induced platelet aggregation and is responsible for platelet shape change. ${ }^{218}$ However, without 
$\mathrm{P}_{12} \mathrm{Y}_{12}$ activation, the result is a small and reversible platelet aggregation. $\mathrm{P} \mathrm{Y}_{12}$ stimulation results in amplification and stabilization of the aggregation response. There is a complex interplay between $\mathrm{P}_{2} \mathrm{Y}_{1}$ and $\mathrm{P}_{2} \mathrm{Y}_{12},{ }^{219}$ and coactivation of both is necessary for full platelet aggregation. ${ }^{220}$ Due to its prominent role in platelet aggregation, the $\mathrm{P}_{2} \mathrm{Y}_{12}$ receptor has become a major target of antiplatelet therapy (-Fig. 2), ${ }^{68,221,222}$ and the prescription of a $\mathrm{P}^{2} \mathrm{Y}_{12}$ receptor antagonist in addition to aspirin is the current standard of care in patients with acute coronary syndromes and in those undergoing percutaneous cardiovascular interventions with stent implantation. ${ }^{223-225}$ In contrast, no antagonists of the $\mathrm{P}_{2} \mathrm{Y}_{1}$ receptor have been approved for clinical use.

\section{Conclusion}

New imaging techniques as well as in vitro and in vivo studies have resulted in a comprehensive view of platelet structure, secretion, adhesion, and activation, thereby providing the foundation of today's understanding of the role of platelets in health and disease. Nevertheless, there still remain numerous knowledge gaps with regard to platelet physiology and pathophysiology, which offer promising targets for further investigations. Most important, evolving knowledge on platelets needs to be integrated in future research efforts with the ultimate goal of improving patient care.

\section{References}

1 Michelson AD. Platelets. 3rd ed. San Diego: Elsevier/Academic Press; 2013

2 de Gaetano G, Cerletti C. Platelet adhesion and aggregation and fibrin formation in flowing blood: a historical contribution by Giulio Bizzozero. Platelets 2002;13(2):85-89

3 Brewer DB. Max Schultze (1865), G. Bizzozero (1882) and the discovery of the platelet. Br J Haematol 2006;133(3):251-258

4 Ruggeri ZM. Platelets in atherothrombosis. Nat Med 2002;8(11): 1227-1234

5 Davì G, Patrono C. Platelet activation and atherothrombosis. N Engl J Med 2007;357(24):2482-2494

6 Lindemann S, Krämer B, Seizer P, Gawaz M. Platelets, inflammation and atherosclerosis. J Thromb Haemost 2007;5(Suppl 1): 203-211

7 Engelmann B, Massberg S. Thrombosis as an intravascular effector of innate immunity. Nat Rev Immunol 2013;13(1):34-45

8 Gay LJ, Felding-Habermann B. Contribution of platelets to tumour metastasis. Nat Rev Cancer 2011;11(2):123-134

9 Bessis M. Living Blood Cells and Their Ultrastructure. New York: Springer-Verlag; 1973

10 White JG. Platelet structure. In: Michelson AD ed. Platelets, 3rd ed. San Diego: Elsevier/Academic Press; 2013:117-144

11 White JG, Escolar G. Current concepts of platelet membrane response to surface activation. Platelets 1993;4(4):175-189

12 Kunicki TJ. Platelet glycoprotein antigens and immune receptors. Prog Clin Biol Res 1988;283:87-123

13 White JG, Krumwiede MD, Cocking-Johnson DJ, Escolar G. Dynamic redistribution of glycoprotein Ib/IX on surface-activated platelets. A second look. Am J Pathol 1995;147(4):1057-1067

14 White JG, Krumwiede MD, Johnson DK, Escolar G. Redistribution of GPIb/IX and GPIIb/IIIa during spreading of discoid platelets. Br J Haematol 1995;90(3):633-644

15 White JG, Conard WJ. The fine structure of freeze-fractured blood platelets. Am J Pathol 1973;70(1):45-56
16 Behnke O. The morphology of blood platelet membrane systems. Ser Haematol 1970;3(4):3-16

17 Del Conde I, Shrimpton CN, Thiagarajan P, López JA. Tissue-factorbearing microvesicles arise from lipid rafts and fuse with activated platelets to initiate coagulation. Blood 2005;106(5): 1604-1611

18 White JG. The submembrane filaments of blood platelets. Am J Pathol 1969;56(2):267-277

19 Hartwig JH, DeSisto M. The cytoskeleton of the resting human blood platelet: structure of the membrane skeleton and its attachment to actin filaments. J Cell Biol 1991;112(3):407-425

20 Haydon GB, Taylor DA. Microtubules in hamster platelets. J Cell Biol 1965;26(2):673-676

21 Behnke O. Further studies on microtubules. A marginal bundle in human and rat thrombocytes. J Ultrastruct Res 1965;13(5): 469-477

22 Bessis M, Breton-Gorius J. Microtubules and fibrils in spread-out platelets [in French]. Nouv Rev Fr Hematol 1965;5(4):657-662

23 White JG, Krivit W. An ultrastructural basis for the shape changes induced in platelets by chilling. Blood 1967;30(5):625-635

24 White JG. Effects of colchicine and vinca alkaloids on human platelets. II. Changes in the dense tubular system and formation of an unusual inclusion in incubated cells. Am J Pathol 1968;53(3): 447-461

25 Escolar G, Krumwiede M, White JG. Organization of the actin cytoskeleton of resting and activated platelets in suspension. Am J Pathol 1986;123(1):86-94

26 White JG. Fine structural alterations induced in platelets by adenosine diphosphate. Blood 1968;31(5):604-622

27 White JG, Krumwiede M. Further studies of the secretory pathway in thrombin-stimulated human platelets. Blood 1987;69(4): 1196-1203

28 White JG. Platelet glycosomes. Platelets 1999;10(4):242-246

29 White JG. Electron dense chains and clusters in human platelets. Platelets 2002;13(5-6):317-325

30 White JG. Medich giant platelet disorder: a unique alpha granule deficiency I. Structural abnormalities. Platelets 2004;15(6): 345-353

31 King SM, Reed GL. Development of platelet secretory granules. Semin Cell Dev Biol 2002;13(4):293-302

32 Reed GL. Platelet secretory mechanisms. Semin Thromb Hemost 2004;30(4):441-450

33 White JG, Clawson CC. Development of giant granules in platelets during prolonged storage. Am J Pathol 1980;101(3):635-646

34 Krishnamurti L, Neglia JP, Nagarajan R, et al. Paris-Trousseau syndrome platelets in a child with Jacobsen's syndrome. Am J Hematol 2001;66(4):295-299

35 White JG, Key NS, King RA, Vercellotti GM. The White platelet syndrome: a new autosomal dominant platelet disorder. Platelets 2004;15(3):173-184

36 White JG. Tubular elements in platelet granules. Blood 1968; 32(1):148-156

37 Berger G, Massé JM, Cramer EM. Alpha-granule membrane mirrors the platelet plasma membrane and contains the glycoproteins Ib, IX, and V. Blood 1996;87(4):1385-1395

38 White JG. Electron-dense chains and clusters in platelets from patients with storage pool-deficiency disorders. J Thromb Haemost 2003;1(1):74-79

39 Statland BE, Heagan BM, White JG. Uptake of calcium by platelet relaxing factor. Nature 1969;223(5205):521-522

40 White JG. Golgi complexes in hypogranular platelet syndromes. Platelets 2005;16(1):51-60

41 Behnke O. Electron microscopic observations on the membrane systems of the rat blood platelet. Anat Rec 1967;158(2):121-137

42 Behnke O. An electron microscope study of the megacaryocyte of the rat bone marrow. I. The development of the demarcation membrane system and the platelet surface coat. J Ultrastruct Res 1968;24(5):412-433 
43 Breton-Gorius J. Development of two distinct membrane systems associated in giant complexes in pathological megakaryocytes. Ser Haematol 1975;8(1):49-67

44 White JG, Escolar G. The blood platelet open canalicular system: a two-way street. Eur J Cell Biol 1991;56(2):233-242

45 Escolar G, White JG. The platelet open canalicular system: a final common pathway. Blood Cells 1991;17(3):467-485, discussion 486-495

46 White JG, Clawson CC. Effects of small latex particle uptake on the surface connected canalicular system of blood platelets: a freezefracture and cytochemical study. Diagn Histopathol 1982;5(1): 3-10

47 Escolar G, Leistikow E, White JG. The fate of the open canalicular system in surface and suspension-activated platelets. Blood 1989;74(6):1983-1988

48 White JG. Platelets are covercytes, not phagocytes: uptake of bacteria involves channels of the open canalicular system. Platelets 2005;16(2):121-131

49 Tranzer JP, Da Prada M, Pletscher A. Ultrastructural localization of 5-hydroxytryptamine in blood platelets. Nature 1966; 212(5070):1574-1575

50 Siegel A, Lüscher EF. Non-identity of the alpha-granules of human blood platelets with typical lysosomes. Nature 1967;215(5102): 745-747

51 Flaumenhaft R. Platelet secretion. In: Michelson AD ed. Platelets, 3rd ed. San Diego: Elsevier/Academic Press; 2013: 343-366

52 Cramer EM, Harrison P, Savidge GF, et al. Uncoordinated expression of alpha-granule proteins in human megakaryocytes. Prog Clin Biol Res 1990;356:131-142

53 Hegyi E, Heilbrun LK, Nakeff A. Immunogold probing of platelet factor 4 in different ploidy classes of rat megakaryocytes sorted by flow cytometry. Exp Hematol 1990;18(7):789-793

54 Hitchcock IS, Chen MM, King JR, Kaushansky K. YRRL motifs in the cytoplasmic domain of the thrombopoietin receptor regulate receptor internalization and degradation. Blood 2008;112(6): 2222-2231

55 Heijnen HF, Debili N, Vainchencker W, Breton-Gorius J, Geuze HJ, Sixma JJ. Multivesicular bodies are an intermediate stage in the formation of platelet alpha-granules. Blood 1998;91(7): 2313-2325

56 Youssefian T, Cramer EM. Megakaryocyte dense granule components are sorted in multivesicular bodies. Blood 2000;95(12): 4004-4007

57 Heijnen HF, Schiel AE, Fijnheer R, Geuze HJ, Sixma JJ. Activated platelets release two types of membrane vesicles: microvesicles by surface shedding and exosomes derived from exocytosis of multivesicular bodies and alpha-granules. Blood 1999;94(11): 3791-3799

58 Raposo G, Marks MS, Cutler DF. Lysosome-related organelles: driving post-Golgi compartments into specialisation. Curr Opin Cell Biol 2007;19(4):394-401

59 Huang L, Kuo YM, Gitschier J. The pallid gene encodes a novel, syntaxin 13-interacting protein involved in platelet storage pool deficiency. Nat Genet 1999;23(3):329-332

60 Falcón-Pérez JM, Starcevic M, Gautam R, Dell'Angelica EC. BLOC-1, a novel complex containing the pallidin and muted proteins involved in the biogenesis of melanosomes and platelet-dense granules. J Biol Chem 2002;277(31):28191-28199

61 Nazarian R, Falcón-Pérez JM, Dell'Angelica EC. Biogenesis of lysosome-related organelles complex 3 (BLOC-3): a complex containing the Hermansky-Pudlak syndrome (HPS) proteins HPS1 and HPS4. Proc Natl Acad Sci U S A 2003;100(15): 8770-8775

62 Kloer DP, Rojas R, Ivan V, et al. Assembly of the biogenesis of lysosome-related organelles complex-3 (BLOC-3) and its interaction with Rab9. J Biol Chem 2010;285(10):7794-7804
63 Huizing M, Parkes JM, Helip-Wooley A, White JG, Gahl WA. Platelet alpha granules in BLOC-2 and BLOC-3 subtypes of Hermansky-Pudlak syndrome. Platelets 2007;18(2):150-157

64 Maynard DM, Heijnen HF, Horne MK, White JG, Gahl WA. Proteomic analysis of platelet alpha-granules using mass spectrometry. J Thromb Haemost 2007;5(9):1945-1955

65 Nurden P, Jandrot-Perrus M, Combrié R, et al. Severe deficiency of glycoprotein VI in a patient with gray platelet syndrome. Blood 2004;104(1):107-114

66 Michelson AD, Furman MI. Laboratory markers of platelet activation and their clinical significance. Curr Opin Hematol 1999;6(5): 342-348

67 Michelson AD. Flow cytometry: a clinical test of platelet function. Blood 1996;87(12):4925-4936

68 Michelson AD. Antiplatelet therapies for the treatment of cardiovascular disease. Nat Rev Drug Discov 2010;9(2):154-169

69 Coppinger JA, Cagney G, Toomey S, et al. Characterization of the proteins released from activated platelets leads to localization of novel platelet proteins in human atherosclerotic lesions. Blood 2004;103(6):2096-2104

70 Holmsen H, Weiss HJ. Secretable storage pools in platelets. Annu Rev Med 1979;30:119-134

71 Ruiz FA, Lea CR, Oldfield E, Docampo R. Human platelet dense granules contain polyphosphate and are similar to acidocalcisomes of bacteria and unicellular eukaryotes. J Biol Chem 2004; 279(43):44250-44257

72 Aikawa M, Schoenbechler MJ, Barbaro JF, Sadun EH. Interaction of rabbit platelets and leukocytes in the release of histamine. Electron microscopic observations. Am J Pathol 1971;63(1): 85-98

73 Dean GE, Fishkes H, Nelson PJ, Rudnick G. The hydrogen ionpumping adenosine triphosphatase of platelet dense granule membrane. Differences from F1F0- and phosphoenzyme-type ATPases. J Biol Chem 1984;259(15):9569-9574

74 Jedlitschky G, Tirschmann K, Lubenow LE, et al. The nucleotide transporter MRP4 (ABCC4) is highly expressed in human platelets and present in dense granules, indicating a role in mediator storage. Blood 2004;104(12):3603-3610

75 Fukami MH, Holmsen H, Ugurbil K. Histamine uptake in pig platelets and isolated dense granules. Biochem Pharmacol 1984;33(23):3869-3874

76 Youssefian T, Massé JM, Rendu F, Guichard J, Cramer EM. Platelet and megakaryocyte dense granules contain glycoproteins Ib and IIb-IIIa. Blood 1997;89(11):4047-4057

77 Ginsberg MH, Taylor L, Painter RG. The mechanism of thrombininduced platelet factor 4 secretion. Blood 1980;55(4):661-668

78 Stenberg PE, Shuman MA, Levine SP, Bainton DF. Redistribution of alpha-granules and their contents in thrombin-stimulated platelets. J Cell Biol 1984;98(2):748-760

79 Morgenstern E, Neumann K, Patscheke H. The exocytosis of human blood platelets. A fast freezing and freeze-substitution analysis. Eur J Cell Biol 1987;43(2):273-282

80 Feng D, Crane K, Rozenvayn N, Dvorak AM, Flaumenhaft R. Subcellular distribution of 3 functional platelet SNARE proteins: human cellubrevin, SNAP-23, and syntaxin 2. Blood 2002;99(11): 4006-4014

81 Ferro-Novick S, Jahn R. Vesicle fusion from yeast to man. Nature 1994;370(6486):191-193

82 Ren Q Barber HK, Crawford GL, et al. Endobrevin/VAMP-8 is the primary v-SNARE for the platelet release reaction. Mol Biol Cell 2007;18(1):24-33

83 Schraw TD, Rutledge TW, Crawford GL, et al. Granule stores from cellubrevin/VAMP-3 null mouse platelets exhibit normal stimulus-induced release. Blood 2003;102(5):1716-1722

84 Dowal L, Yang W, Freeman MR, Steen H, Flaumenhaft R. Proteomic analysis of palmitoylated platelet proteins. Blood 2011; 118(13):e62-e73 
85 Lai KC, Flaumenhaft R. SNARE protein degradation upon platelet activation: calpain cleaves SNAP-23. J Cell Physiol 2003;194(2): 206-214

86 Flaumenhaft R, Croce K, Chen E, Furie B, Furie BC. Proteins of the exocytotic core complex mediate platelet alpha-granule secretion. Roles of vesicle-associated membrane protein, SNAP-23, and syntaxin 4. J Biol Chem 1999;274(4):2492-2501

87 Polgár J, Reed GL. A critical role for N-ethylmaleimide-sensitive fusion protein (NSF) in platelet granule secretion. Blood 1999; 94(4):1313-1318

88 Lemons PP, Chen D, Whiteheart SW. Molecular mechanisms of platelet exocytosis: requirements for alpha-granule release. Biochem Biophys Res Commun 2000;267(3):875-880

89 Sandrock K, Nakamura L, Vraetz T, Beutel K, Ehl S, Zieger B. Platelet secretion defect in patients with familial hemophagocytic lymphohistiocytosis type 5 (FHL-5). Blood 2010;116(26): 6148-6150

90 Houng A, Polgar J, Reed GL. Munc18-syntaxin complexes and exocytosis in human platelets. J Biol Chem 2003;278(22): 19627-19633

91 Karniguian A, Zahraoui A, Tavitian A. Identification of small GTPbinding rab proteins in human platelets: thrombin-induced phosphorylation of rab3B, rab6, and rab8 proteins. Proc Natl Acad Sci U S A 1993;90(16):7647-7651

92 Fitzgerald ML, Reed GL. Rab6 is phosphorylated in thrombinactivated platelets by a protein kinase C-dependent mechanism: effects on GTP/GDP binding and cellular distribution. Biochem J 1999;342(Pt 2):353-360

93 Tolmachova T, Anders R, Stinchcombe J, et al. A general role for Rab27a in secretory cells. Mol Biol Cell 2004;15(1):332-344

94 Tolmachova T, Abrink M, Futter CE, Authi KS, Seabra MC. Rab27b regulates number and secretion of platelet dense granules. Proc Natl Acad Sci U S A 2007;104(14):5872-5877

95 Ge S, Wittenberg NJ, Haynes CL. Quantitative and real-time detection of secretion of chemical messengers from individual platelets. Biochemistry 2008;47(27):7020-7024

96 Flaumenhaft R, Dilks JR, Rozenvayn N, Monahan-Earley RA, Feng $D$, Dvorak AM. The actin cytoskeleton differentially regulates platelet alpha-granule and dense-granule secretion. Blood 2005; 105(10):3879-3887

97 Muallem S, Kwiatkowska K, Xu X, Yin HL. Actin filament disassembly is a sufficient final trigger for exocytosis in nonexcitable cells. J Cell Biol 1995;128(4):589-598

98 Suzuki Y, Yamamoto M, Wada H, et al. Agonist-induced regulation of myosin phosphatase activity in human platelets through activation of Rho-kinase. Blood 1999;93(10):3408-3417

99 Watanabe Y, Ito M, Kataoka Y, et al. Protein kinase C-catalyzed phosphorylation of an inhibitory phosphoprotein of myosin phosphatase is involved in human platelet secretion. Blood 2001;97(12):3798-3805

100 Nishikawa M, Tanaka T, Hidaka H. Ca2+-calmodulin-dependent phosphorylation and platelet secretion. Nature 1980;287(5785): 863-865

101 Kunert S, Meyer I, Fleischhauer S, et al. The microtubule modulator RanBP10 plays a critical role in regulation of platelet discoid shape and degranulation. Blood 2009;114(27): 5532-5540

102 Schwer HD, Lecine P, Tiwari S, Italiano JE Jr, Hartwig JH, Shivdasani RA. A lineage-restricted and divergent beta-tubulin isoform is essential for the biogenesis, structure and function of blood platelets. Curr Biol 2001;11(8):579-586

103 Knight DE, Scrutton MC. Direct evidence for a role for $\mathrm{Ca} 2+$ in amine storage granule secretion by human platelets. Thromb Res 1980;20(4):437-446

104 Gilio K, Harper MT, Cosemans JM, et al. Functional divergence of platelet protein kinase C (PKC) isoforms in thrombus formation on collagen. J Biol Chem 2010;285(30):23410-23419
105 Nagy B Jr, Bhavaraju K, Getz T, Bynagari YS, Kim S, Kunapuli SP. Impaired activation of platelets lacking protein kinase C-theta isoform. Blood 2009;113(11):2557-2567

106 Chari R, Getz T, Nagy B Jr, et al. Protein kinase C[delta] differentially regulates platelet functional responses. Arterioscler Thromb Vasc Biol 2009;29(5):699-705

107 Suzuki H, Murasaki K, Kodama K, Takayama H. Intracellular localization of glycoprotein VI in human platelets and its surface expression upon activation. Br J Haematol 2003;121(6):904-912

108 Romp KG, Monroe DM, Hoffman M. Platelets contain releasable coagulation factor IX antigen. Blood Coagul Fibrinolysis 1993; 4(6):905-910

109 Schwarz HP, Heeb MJ, Wencel-Drake JD, Griffin JH. Identification and quantitation of protein $S$ in human platelets. Blood 1985; 66(6):1452-1455

110 Novotny WF, Girard TJ, Miletich JP, Broze GJ Jr. Platelets secrete a coagulation inhibitor functionally and antigenically similar to the lipoprotein associated coagulation inhibitor. Blood 1988;72(6): 2020-2025

111 Nurden AT, Nurden P. The gray platelet syndrome: clinical spectrum of the disease. Blood Rev 2007;21(1):21-36

112 Golino P, Crea F, Willerson JT. How to study the effects of platelet aggregation and thrombosis on coronary vasomotion and their clinical relevance. Ital Heart J 2002;3(4):220-225

113 Louie S, Kim BK, Zamecnik P. Diadenosine 5',5"'-P1,P4-tetraphosphate, a potential antithrombotic agent. Thromb Res 1988;49(6): 557-565

114 Chang H, Yanachkov IB, Michelson AD, et al. Agonist and antagonist effects of diadenosine tetraphosphate, a platelet dense granule constituent, on platelet $\mathrm{P} 2 \mathrm{Y} 1, \mathrm{P} 2 \mathrm{Y} 12$ and $\mathrm{P} 2 \times 1$ receptors. Thromb Res 2010;125(2):159-165

115 Weiss HJ, Turitto VT, Baumgartner HR. Platelet adhesion and thrombus formation on subendothelium in platelets deficient in glycoproteins IIb-IIIa, Ib, and storage granules. Blood 1986;67(2): 322-330

116 Graham GJ, Ren Q, Dilks JR, Blair P, Whiteheart SW, Flaumenhaft R. Endobrevin/VAMP-8-dependent dense granule release mediates thrombus formation in vivo. Blood 2009;114(5):1083-1090

117 Larsen E, Palabrica T, Sajer S, et al. PADGEM-dependent adhesion of platelets to monocytes and neutrophils is mediated by a lineagespecific carbohydrate, LNF III (CD15). Cell 1990;63(3):467-474

118 Diacovo TG, Puri KD, Warnock RA, Springer TA, von Andrian UH. Platelet-mediated lymphocyte delivery to high endothelial venules. Science 1996;273(5272):252-255

119 Zarbock A, Singbartl K, Ley K. Complete reversal of acid-induced acute lung injury by blocking of platelet-neutrophil aggregation. J Clin Invest 2006;116(12):3211-3219

120 Gleissner CA, von Hundelshausen P, Ley K. Platelet chemokines in vascular disease. Arterioscler Thromb Vasc Biol 2008;28(11): 1920-1927

121 Brandt E, Petersen F, Ludwig A, Ehlert JE, Bock L, Flad HD. The beta-thromboglobulins and platelet factor 4: blood plateletderived CXC chemokines with divergent roles in early neutrophil regulation. J Leukoc Biol 2000;67(4):471-478

122 Slungaard A. Platelet factor 4: a chemokine enigma. Int J Biochem Cell Biol 2005;37(6):1162-1167

123 Kasper B, Brandt E, Bulfone-Paus S, Petersen F. Platelet factor 4 (PF-4)-induced neutrophil adhesion is controlled by src-kinases, whereas PF-4-mediated exocytosis requires the additional activation of p38 MAP kinase and phosphatidylinositol 3-kinase. Blood 2004;103(5):1602-1610

124 von Hundelshausen P, Petersen F, Brandt E. Platelet-derived chemokines in vascular biology. Thromb Haemost 2007;97(5): 704-713

125 Müller F, Mutch NJ, Schenk WA, et al. Platelet polyphosphates are proinflammatory and procoagulant mediators in vivo. Cell 2009; 139(6):1143-1156 
126 Paigen B, Holmes PA, Novak EK, Swank RT. Analysis of atherosclerosis susceptibility in mice with genetic defects in platelet function. Arteriosclerosis 1990;10(4):648-652

127 Klinger MH, Jelkmann W. Role of blood platelets in infection and inflammation. J Interferon Cytokine Res 2002;22(9):913-922

128 Rendu F, Brohard-Bohn B. The platelet release reaction: granules' constituents, secretion and functions. Platelets 2001;12(5): 261-273

129 Brill A, Elinav H, Varon D. Differential role of platelet granular mediators in angiogenesis. Cardiovasc Res 2004;63(2): 226-235

130 Italiano JE Jr, Richardson JL, Patel-Hett S, et al. Angiogenesis is regulated by a novel mechanism: pro- and antiangiogenic proteins are organized into separate platelet alpha granules and differentially released. Blood 2008;111(3):1227-1233

131 Ma L, Perini R, McKnight W, et al. Proteinase-activated receptors 1 and 4 counter-regulate endostatin and VEGF release from human platelets. Proc Natl Acad Sci U S A 2005;102(1):216-220

132 Battinelli EM, Markens BA, Italiano JE Jr. Release of angiogenesis regulatory proteins from platelet alpha granules: modulation of physiologic and pathologic angiogenesis. Blood 2011;118(5): 1359-1369

133 Ho-Tin-Noé B, Goerge T, Cifuni SM, Duerschmied D, Wagner DD. Platelet granule secretion continuously prevents intratumor hemorrhage. Cancer Res 2008;68(16):6851-6858

134 Karpatkin S, Pearlstein E, Salk PL, Yogeeswaran G. Role of platelets in tumor cell metastases. Ann N Y Acad Sci 1981;370:101-118

135 Nash GF, Turner LF, Scully MF, Kakkar AK. Platelets and cancer. Lancet Oncol 2002;3(7):425-430

136 Nagai M, Sato S, Kamoi H, Kamoi K. Effects of application of platelet releasate in periodontal regeneration therapy. Int J Periodontics Restorative Dent 2005;25(6):571-583

137 Moulin V, Lawny F, Barritault D, Caruelle JP. Platelet releasate treatment improves skin healing in diabetic rats through endogenous growth factor secretion. Cell Mol Biol (Noisy-le-grand) 1998;44(6):961-971

138 Clemetson KJ, Clemetson JM. Platelet receptors. In: Michelson AD ed. Platelets, 3rd ed. San Diego: Elsevier/Academic Press; 2013: 169-194

139 Andrews RK, Gardiner EE, Shen Y, Whisstock JC, Berndt MC. Glycoprotein Ib-IX-V. Int J Biochem Cell Biol 2003;35(8): 1170-1174

140 Andrews RK, Gardiner EE, Shen Y, Berndt MC. Platelet interactions in thrombosis. IUBMB Life 2004;56(1):13-18

141 Andrews RK, Berndt MC. The GPIb-IX-V complex. In: Michelson AD ed. Platelets, 3rd ed. San Diego: Elsevier/Academic Press; 2013:195-213

142 López JA, Andrews RK, Afshar-Kharghan V, Berndt MC. BernardSoulier syndrome. Blood 1998;91(12):4397-4418

143 López JA. The platelet glycoprotein Ib-IX complex. Blood Coagul Fibrinolysis 1994;5(1):97-119

144 Lopez JA, Chung DW, Fujikawa K, Hagen FS, Papayannopoulou T, Roth GJ. Cloning of the alpha chain of human platelet glycoprotein Ib: a transmembrane protein with homology to leucine-rich alpha 2-glycoprotein. Proc Natl Acad Sci U S A 1987;84(16): 5615-5619

145 Kauskot A, Hoylaerts MF. Platelet receptors. Handbook Exp Pharmacol 2012;210(210):23-57

146 Nieswandt B, Watson SP. Platelet-collagen interaction: is GPVI the central receptor? Blood 2003;102(2):449-461

147 Jurk K, Clemetson KJ, de Groot PG, et al. Thrombospondin-1 mediates platelet adhesion at high shear via glycoprotein Ib (GPIb): an alternative/backup mechanism to von Willebrand factor. FASEB J 2003;17(11):1490-1492

148 Romo GM, Dong JF, Schade AJ, et al. The glycoprotein Ib-IX-V complex is a platelet counterreceptor for P-selectin. J Exp Med 1999;190(6):803-814
149 Simon DI, Chen Z, Xu H, et al. Platelet glycoprotein ibalpha is a counterreceptor for the leukocyte integrin Mac-1 (CD11b/CD18). J Exp Med 2000;192(2):193-204

150 Baglia FA, Badellino KO, Li CQ Lopez JA, Walsh PN. Factor XI binding to the platelet glycoprotein Ib-IX-V complex promotes factor XI activation by thrombin. J Biol Chem 2002;277(3): 1662-1668

151 Joseph K, Nakazawa Y, Bahou WF, Ghebrehiwet B, Kaplan AP Platelet glycoprotein Ib: a zinc-dependent binding protein for the heavy chain of high-molecular-weight kininogen. Mol Med 1999; 5(8):555-563

152 Bradford HN, Pixley RA, Colman RW. Human factor XII binding to the glycoprotein Ib-IX-V complex inhibits thrombin-induced platelet aggregation. J Biol Chem 2000;275(30):22756-22763

153 Gardiner EE, Arthur JF, Shen Y, et al. GPIbalpha-selective activation of platelets induces platelet signaling events comparable to GPVI activation events. Platelets 2010;21(4):244-252

154 Schulte am Esch J II, Cruz MA, Siegel JB, Anrather J, Robson SC. Activation of human platelets by the membrane-expressed A1 domain of von Willebrand factor. Blood 1997;90(11):4425-4437

155 Kasirer-Friede A, Cozzi MR, Mazzucato M, De Marco L, Ruggeri ZM, Shattil SJ. Signaling through GP Ib-IX-V activates alpha IIb beta 3 independently of other receptors. Blood 2004;103(9): 3403-3411

156 Furihata K, Clemetson KJ, Deguchi H, Kunicki TJ. Variation in human platelet glycoprotein VI content modulates glycoprotein VI-specific prothrombinase activity. Arterioscler Thromb Vasc Biol 2001;21(11):1857-1863

157 Best D, Senis YA, Jarvis GE, et al. GPVI levels in platelets: relationship to platelet function at high shear. Blood 2003; 102(8):2811-2818

158 Samaha FF, Hibbard C, Sacks J, et al. Density of platelet collagen receptors glycoprotein VI and alpha2beta1 and prior myocardial infarction in human subjects, a pilot study. Med Sci Monit 2005; 11(5):CR224-CR229

159 Senis YA, Tomlinson MG, Ellison S, et al. The tyrosine phosphatase CD148 is an essential positive regulator of platelet activation and thrombosis. Blood 2009;113(20):4942-4954

160 Pollitt AY, Hughes CE, Watson SP. GPVI and CLEC-2. I In: Michelson AD ed. Platelets, 3rd ed. San Diego: Elsevier/Academic Press; 2013:215-231

161 Andrews RK, Suzuki-Inoue K, Shen Y, Tulasne D, Watson SP, Berndt MC. Interaction of calmodulin with the cytoplasmic domain of platelet glycoprotein VI. Blood 2002;99(11): 4219-4221

162 Suzuki-Inoue K, Tulasne D, Shen Y, et al. Association of Fyn and Lyn with the proline-rich domain of glycoprotein VI regulates intracellular signaling. J Biol Chem 2002;277(24):21561-21566

163 Berlanga O, Bori-Sanz T, James JR, et al. Glycoprotein VI oligomerization in cell lines and platelets. J Thromb Haemost 2007;5(5): 1026-1033

164 Miura Y, Takahashi T, Jung SM, Moroi M. Analysis of the interaction of platelet collagen receptor glycoprotein VI (GPVI) with collagen. A dimeric form of GPVI, but not the monomeric form, shows affinity to fibrous collagen. J Biol Chem 2002;277(48): 46197-46204

165 Jung SM, Tsuji K, Moroi M. Glycoprotein (GP) VI dimer as a major collagen-binding site of native platelets: direct evidence obtained with dimeric GPVI-specific Fabs. J Thromb Haemost 2009;7(8): 1347-1355

166 Zahid M, Loyau S, Bouabdelli M, Aubrey N, Jandrot-Perrus M, Billiald P. Design and reshaping of an $\mathrm{scFv}$ directed against human platelet glycoprotein VI with diagnostic potential. Anal Biochem 2011;417(2):274-282

167 Nieswandt B, Bergmeier W, Schulte V, Rackebrandt K, Gessner JE, Zirngibl $\mathrm{H}$. Expression and function of the mouse collagen receptor glycoprotein VI is strictly dependent on its association 
with the FcRgamma chain. J Biol Chem 2000;275(31): 23998-24002

168 Watson S, Berlanga O, Best D, Frampton J. Update on collagen receptor interactions in platelets: is the two-state model still valid? Platelets 2000;11(5):252-258

169 Nieswandt B, Brakebusch C, Bergmeier W, et al. Glycoprotein VI but not alpha2beta1 integrin is essential for platelet interaction with collagen. EMBO J 2001;20(9):2120-2130

170 Hermans C, Wittevrongel C, Thys C, Smethurst PA, Van Geet C, Freson K. A compound heterozygous mutation in glycoprotein VI in a patient with a bleeding disorder. J Thromb Haemost 2009; 7(8):1356-1363

171 Dumont B, Lasne D, Rothschild C, et al. Absence of collageninduced platelet activation caused by compound heterozygous GPVI mutations. Blood 2009;114(9):1900-1903

172 Ho-Tin-Noé B, Demers M, Wagner DD. How platelets safeguard vascular integrity. J Thromb Haemost 2011;9(Suppl 1):56-65

173 Echtler K, Stark K, Lorenz M, et al. Platelets contribute to postnatal occlusion of the ductus arteriosus. Nat Med 2010;16(1):75-82

174 Boilard E, Nigrovic PA, Larabee K, et al. Platelets amplify inflammation in arthritis via collagen-dependent microparticle production. Science 2010;327(5965):580-583

175 Bennett JS. The molecular biology of platelet membrane proteins. Semin Hematol 1990;27(2):186-204

176 Plow EF, Byzova T. The biology of glycoprotein IIb-IIIa. Coron Artery Dis 1999;10(8):547-551

177 Hynes RO. Integrins: bidirectional, allosteric signaling machines. Cell 2002;110(6):673-687

178 Ruoslahti E, Engvall E. Integrins and vascular extracellular matrix assembly. J Clin Invest 1997;99(6):1149-1152

179 Beer AJ, Schwaiger M. Imaging of integrin alphavbeta3 expression. Cancer Metastasis Rev 2008;27(4):631-644

180 Uzan G, Prenant M, Prandini MH, Martin F, Marguerie G. Tissuespecific expression of the platelet GPIIb gene. J Biol Chem 1991; 266(14):8932-8939

181 Trikha M, Timar J, Lundy SK, et al. Human prostate carcinoma cells express functional alphallb(beta)3 integrin. Cancer Res 1996; 56(21):5071-5078

182 Emambokus NR, Frampton J. The glycoprotein IIb molecule is expressed on early murine hematopoietic progenitors and regulates their numbers in sites of hematopoiesis. Immunity 2003; 19(1):33-45

183 Oki T, Kitaura J, Eto K, et al. Integrin alphallbbeta3 induces the adhesion and activation of mast cells through interaction with fibrinogen. J Immunol 2006;176(6):3841

184 Oki T, Eto K, Izawa K, et al. Evidence that integrin alpha IIb beta 3dependent interaction of mast cells with fibrinogen exacerbates chronic inflammation. J Biol Chem 2009;284(45):31463-31472

185 Sheldrake HM, Patterson LH. Function and antagonism of beta3 integrins in the development of cancer therapy. Curr Cancer Drug Targets 2009;9(4):519-540

186 Niiya K, Hodson E, Bader R, et al. Increased surface expression of the membrane glycoprotein IIb/IIIa complex induced by platelet activation. Relationship to the binding of fibrinogen and platelet aggregation. Blood 1987;70(2):475-483

187 Wagner CL, Mascelli MA, Neblock DS, Weisman HF, Coller BS, Jordan RE. Analysis of GPIIb/IIIa receptor number by quantification of 7E3 binding to human platelets. Blood 1996;88(3): 907-914

188 Phillips DR, Charo IF, Parise LV, Fitzgerald LA. The platelet membrane glycoprotein IIb-IIla complex. Blood 1988;71(4): 831-843

189 Wencel-Drake JD, Plow EF, Kunicki TJ, Woods VL, Keller DM, Ginsberg MH. Localization of internal pools of membrane glycoproteins involved in platelet adhesive responses. Am J Pathol 1986;124(2):324-334

190 Woods VL Jr, Wolff LE, Keller DM. Resting platelets contain a substantial centrally located pool of glycoprotein IIb-IIla complex which may be accessible to some but not other extracellular proteins. J Biol Chem 1986;261(32):15242-15251

191 Fujimura K, Phillips DR. Calcium cation regulation of glycoprotein IIb-IIIa complex formation in platelet plasma membranes. J Biol Chem 1983;258(17):10247-10252

192 Zhu J, Luo BH, Xiao T, Zhang C, Nishida N, Springer TA. Structure of a complete integrin ectodomain in a physiologic resting state and activation and deactivation by applied forces. Mol Cell 2008; 32(6):849-861

193 Zimrin AB, Gidwitz S, Lord S, et al. The genomic organization of platelet glycoprotein IIIa. J Biol Chem 1990;265(15):8590-8595

194 Fitzgerald LA, Steiner B, Rall SC Jr, Lo SS, Phillips DR. Protein sequence of endothelial glycoprotein IIla derived from a cDNA clone. Identity with platelet glycoprotein IIIa and similarity to “integrin". J Biol Chem 1987;262(9):3936-3939

195 Xiong JP, Stehle T, Diefenbach B, et al. Crystal structure of the extracellular segment of integrin alpha Vbeta3. Science 2001; 294(5541):339-345

196 Xiao T, Takagi J, Coller BS, Wang JH, Springer TA. Structural basis for allostery in integrins and binding to fibrinogen-mimetic therapeutics. Nature 2004;432(7013):59-67

197 Bledzka K, Pesho MM, Ma YQ Plow EF. Integrin $\alpha I I b \beta 3$. In: Michelson AD ed. Platelets, 3rd ed. San Diego: Elsevier/Academic Press; 2013:233-248

198 Savage B, Cattaneo M, Ruggeri ZM. Mechanisms of platelet aggregation. Curr Opin Hematol 2001;8(5):270-276

199 Hynes RO. Integrins: versatility, modulation, and signaling in cell adhesion. Cell 1992;69(1):11-25

200 Plow EF, Haas TA, Zhang L, Loftus J, Smith JW. Ligand binding to integrins. J Biol Chem 2000;275(29):21785-21788

201 Reheman A, Gross P, Yang H, et al. Vitronectin stabilizes thrombi and vessel occlusion but plays a dual role in platelet aggregation.J Thromb Haemost 2005;3(5):875-883

202 Bhatt DL, Topol EJ. Current role of platelet glycoprotein IIb/IIIa inhibitors in acute coronary syndromes. JAMA 2000;284(12): 1549-1558

203 Lischke S, Schneider DJ. Recent developments in the use of antiplatelet agents to prevent cardiovascular events. Future Cardiol 2011;7(3):403-413

204 Jennings LK. Mechanisms of platelet activation: need for new strategies to protect against platelet-mediated atherothrombosis. Thromb Haemost 2009;102(2):248-257

205 Kahn ML, Zheng YW, Huang W, et al. A dual thrombin receptor system for platelet activation. Nature 1998;394(6694): 690-694

206 Leger AJ, Covic L, Kuliopulos A. Protease-activated receptors in cardiovascular diseases. Circulation 2006;114(10):1070-1077

207 Dörmann D, Clemetson KJ, Kehrel BE. The GPIb thrombin-binding site is essential for thrombin-induced platelet procoagulant activity. Blood 2000;96(7):2469-2478

208 Adam F, Guillin MC, Jandrot-Perrus M. Glycoprotein Ib-mediated platelet activation. A signalling pathway triggered by thrombin. Eur J Biochem 2003;270(14):2959-2970

209 De Candia E, Hall SW, Rutella S, Landolfi R, Andrews RK, De Cristofaro R. Binding of thrombin to glycoprotein Ib accelerates the hydrolysis of Par-1 on intact platelets. J Biol Chem 2001; 276(7):4692-4698

210 Zhang P, Covic L, Kuliopulos A. Protease-activated receptors. In: Michelson AD ed. Platelets, 3rd ed. San Diego: Elsevier/Academic Press; 2013:249-259

211 Kahn ML, Nakanishi-Matsui M, Shapiro MJ, Ishihara H, Coughlin SR. Protease-activated receptors 1 and 4 mediate activation of human platelets by thrombin. J Clin Invest 1999;103(6):879-887

212 Nakanishi-Matsui M, Zheng YW, Sulciner DJ, Weiss EJ, Ludeman MJ, Coughlin SR. PAR3 is a cofactor for PAR4 activation by thrombin. Nature 2000;404(6778):609-613

213 De Candia E. Mechanisms of platelet activation by thrombin: a short history. Thromb Res 2012;129(3):250-256 
214 Morrow DA, Braunwald E, Bonaca MP, et al; TRA 2P-TIMI 50 Steering Committee and Investigators. Vorapaxar in the secondary prevention of atherothrombotic events. N Engl J Med 2012; 366(15):1404-1413

215 Tricoci P, Huang Z, Held C, et al; TRACER Investigators. Thrombinreceptor antagonist vorapaxar in acute coronary syndromes. N Engl J Med 2012;366(1):20-33

216 Born GV. Aggregation of blood platelets by adenosine diphosphate and its reversal. Nature 1962;194:927-929

217 Cattaneo M. The platelet P2 receptors. In: Michelson AD ed. Platelets, 3rd ed. San Diego: Elsevier/Academic Press; 2013: 261-281

218 Jin J, Daniel JL, Kunapuli SP. Molecular basis for ADP-induced platelet activation. II. The P2Y1 receptor mediates ADP-induced intracellular calcium mobilization and shape change in platelets. J Biol Chem 1998;273(4):2030-2034

219 Hardy AR, Jones ML, Mundell SJ, Poole AW. Reciprocal cross-talk between P2Y1 and P2Y12 receptors at the level of calcium signaling in human platelets. Blood 2004;104(6):1745-1752
220 Jin J, Kunapuli SP. Coactivation of two different G protein-coupled receptors is essential for ADP-induced platelet aggregation. Proc Natl Acad Sci U S A 1998;95(14):8070-8074

221 Cattaneo M. P2Y12 receptor antagonists: a rapidly expanding group of antiplatelet agents. Eur Heart J 2006;27(9):1010-1012

222 Cattaneo M. New P2Y12 blockers. J Thromb Haemost 2009;7 (Suppl 1):262-265

223 Yusuf S, Zhao F, Mehta SR, Chrolavicius S, Tognoni G, Fox KK; Clopidogrel in Unstable Angina to Prevent Recurrent Events Trial Investigators. Effects of clopidogrel in addition to aspirin in patients with acute coronary syndromes without ST-segment elevation. N Engl J Med 2001;345(7):494-502

224 Wiviott SD, Braunwald E, McCabe $\mathrm{CH}$, et al; TRITON-TIMI 38 Investigators. Prasugrel versus clopidogrel in patients with acute coronary syndromes. N Engl J Med 2007;357(20): 2001-2015

225 Wallentin L, Becker RC, Budaj A, et al; PLATO Investigators. Ticagrelor versus clopidogrel in patients with acute coronary syndromes. N Engl J Med 2009;361(11):1045-1057 